\title{
Analysis of Ideological and Political Education Model in Colleges from the Perspective of Overall Process
}

\author{
Chao Kang \\ School of Literature and Journalism, Neijiang Normal University, \\ Neijiang, 641112, China
}

Keywords: overall process, colleges, ideological and political education, model

\begin{abstract}
As a key in colleges, ideological and political education for college students is directly related to sustainable college development. However, deficiencies in existing college ideological and political education model in the traditional sense affect benign operation of this work. So, an ideological and political education model from the perspective of overall process shall be established positively, in order to guide work of ideological and political education for college students.
\end{abstract}

\section{Introduction}

In terms of social role, colleges, as important places where talents gather, cultivate a large number of compound talents for the society, and thus become an important factor that is related to success of the construction of socialism with Chinese characteristics. So, all walks of life shall highly recognize the important position of colleges, and thus create good conditions for healthy and sustainable development of colleges. Colleges shall respond to the positive call of the party and government, undertake education teaching vigorously, perform their responsibilities and give play to the best effects. Under this situation, strengthening of ideological and political education for college students has become an extremely urgent task in current development. Thus, colleges shall always adhere to the principle of education orientation, and launch overall processed ideological and political education model.

\section{Meaning of overall processed college ideological and political education model}

At present, colleges are trying to explore new ideological and political education models in order to adapt to demands with the change of the times. For example, some colleges explore new education models actively based on reference to advanced experience of western countries combined with their own reality; some create good new education circumstances positively by connecting theories with practice. However, the construction of college ideological and political education model is also a systematic project, and needs guarantee of more advanced concepts, more perfect operating system and more complete supporting facilities. Under this situation, overall processed ideological and political education model comes into being. The author believes that overall processed ideological and political education model is a new model to practically meet social and individual development needs, adapt to current development situation of education teaching, use effective methods such as carrying out classroom teaching, implementing social practice and strengthening educational evaluation etc, fully carry out the goal of education first, and cultivate high-quality college talents positively. Specifically, this new ideological and political education model contains the following two aspects of meaning:

Firstly, in terms of theoretical definition and operating boundaries, overall processed ideological and political education model completely complies with basic meaning and requirements of modeling, and is innovation of college ideological and political education theory and practice. On the one hand, overall processed ideological and political education model can conduct good innovation of guiding system of this theory. This theoretical guiding system always takes socialist core value system as the core, supplemented by other types of social values, and practically conforms to people-oriented education teaching concept. So, penetration of core value system into 
college ideological and political education as main guiding ideology is the innovation of overall processed ideological and political education model. In terms of practical effects, this new model can shape good socialist personality and cultivate college talents' overall qualities. On the other hand, theoretical innovation and system innovation are sources of vitality of overall processed ideological and political education model. This new theoretical model and practice model can reconstruct educational concepts, goals, content and methods etc comprehensively and systematically, can be included into new ideological and political education systems, and thus perfect this education model jointly.

Secondly, overall process is the key variable of this college ideological and political education model, and mainly concerns about continuity of time in college ideological and political education. The view of overall processed ideological and political education model is that the overall process of ideological and political education shall fully adhere to the student-oriented education principle, integrate various categories of educational resources practically and effectively to a maximum degree according to learners' development stage and law of growth, and thus make ideological and political education vibrant and vital. As a systematic work system, overall processed ideological and political education mainly includes a number of different unit systems such as admission stage education, learning process education and educational evaluation etc. This system is featured by rich personality and diverse tasks etc, and thus could not only adhere to scientific and rational education principles, but also practically follow the law of college students' individualized development, realize new development from identical education to differential education and from short-term education to persistent education. So, overall processed ideological and political education model always adheres to the main line of learners' growth, educates college students in persistent time sequence, and always includes educational concepts and value into each different time point or period of college students' growth.

\section{Ways to implement college ideological and political education model from the perspective of overall process}

\section{(I) Ideological and political education course construction system from the perspective of overall process}

Overall processed ideological and political education course system mainly refers to a college ideological and political education course system with ideological and political theoretical teaching course as the center and specialized courses and other courses of college students as the supplement. This ideological and political education course system occurs because: firstly, college ideological and political education has always been a very complex systematic teaching project, and college students' ideological and political awareness cannot be enhanced by merely relying on ideological and political theoretical course, and an overall processed ideological and political education course system shall be established deeply in order to enhance the ability to carry out ideological and political education for college students from many aspects and links. Secondly, college students have different majors, and specialized courses are backbone courses that they learn carefully. So, it is very important to include ideological and political education into teaching of specialized courses for college students, so as to give full play to its role. Therefore, ideological and political education index shall be included into ideological and political education evaluation system to form a sound ideological and political education course construction system. Overall processed ideological and political education course system is to excavate ideological and political education factors in professional ideological and political teaching comprehensively and deeply, and thus build a more systematic and sound ideological and political education work system. So, inclusion of ideological and political education work evaluation into professional course evaluation system can not only enhance college students' understanding of ideological and political education, but also play a more positive role in strengthening the development of college students' professional competence. Take ideological and political theoretical course teaching as the work center and improve effects of ideological and political education continuously. To promote college ideological and political education and realize educational goals, reform of ideological and political education theoretical 
course shall be strengthened, and innovation of education teaching model and course system arrangement shall be carried out. Meanwhile, seek junctions between ideological and political theoretical course and specialized courses continuously, and build an ideological and political education course system with ideological and political theoretical course as the center and specialized courses and other courses as the supplement more actively.

\section{(II) Ideological and political education system at each stage from the perspective of overall} process

In the freshman year, pay attention to enhance cohesion, i.e. practically build collective organizations and form a harmonious atmosphere, so that all college students could be fully devoted to learning. Cultivate actively outstanding students as active applicants for party membership during college freshman entrance education, safety education, behavior and habit development education, freshman psychological adaptation education, collectivism education, class collective education and dormitory cultural construction etc, and have priority in selecting college students who are enthusiastic, hardworking, serious in work and excellent in comprehensive performance to join the Student Union or community organizations, in order to exercise them. Carry out basic knowledge of the party and basic civilization and etiquette education more extensively, and implement patriotism education, law and discipline observation education, ideological and political theoretical education and psychological health education etc. Advocate spirit of diligent studying and profound research actively among college students, guide them to read more books and read good books practically, and promote spirit of pursuing truth actively and dedication to the cause of science. Meanwhile, oppose utilitarianism and falsification etc energetically, apply rites of initiation fully to cultivate students' sense of responsibility, pay more attention to national situation, cultivate their political consciousness, advocate to share cares and burdens of parents and relatives actively, oppose addiction to enjoyment, promote the spirit of innovation actively, oppose negative tendency of no occupation, and thus educate college students learn to deal with people and things.

In the sophomore year, attach importance to competition and development while cohesion has been basically formed. Establish a good atmosphere to help college students establish self-confidence, carry out successful education, make them truly become knowledgeable and talented young people and thus be campus celebrities that others follow and admire. Carry out learning planning education and education related to ideals and faiths etc, enhance college students' interest in and enthusiasm for professional learning, cultivate their ability of practical operation etc, strengthen their research and academic consciousness, and create a stronger academic atmosphere. Invite experts and scholars to give theme lectures more actively and extensively, so as to help college students form a more sound knowledge system. Carry out psychological health education actively and extensively so that students could participate more in various social activities, apply the construction of party organizations and CYL organizations, and promote the formation of good learning and class atmosphere.

In the junior year, exercise and improve competitive strength, in order to lay a good knowledge foundation and ideological quality energy reserves for their future development. Encourage college students to have good academic performance, publish papers in professional journals, and pursue further study in their own colleges actively. Guide college students to pay attention to information related to postgraduate entrance examination, and encourage them to select college and majors that suit for themselves, so as to enhance their competitive strength in entrance examination.

In the senior year, make college students summarize their school work and exchange previous learning experience mutually, in order to test their maturity after many years of ideological and political education, observe their academic ability and level, investigate their individual ideological and moral status, and further strengthen guidance and counseling etc for their postgraduate entrance examination. Try to make students absorb and learn from successful experience of senior students, and provide first-class conditions, so that students who intend to attend the postgraduate entrance examination could achieve the best results. For senior students who prepare to work after graduation, college ideological and political workers shall hold various employment guidance lectures and enterprise job fairs etc actively, so that students could know more about cruel reality of 
the employment market and grasp interview skills thoroughly in order to lay a good foundation for future smooth employment. Meanwhile, carry out career planning education and employment guidance for college graduates by carrying out field enterprise investigation and inviting well-known entrepreneurs to receive interviews in colleges etc. Enhance college students' ability to write documents and deal with things etc through class presentation, teaching practice and graduation thesis (design) etc.

(III) Ideological and political education evaluation system from the perspective of overall process

Evaluation of overall processed ideological and political education is very important for ideological and political education. Evaluation of college ideological and political education is an extremely complex work, including evaluation of both college education process and results of ideological and political education, and evaluation of both hard environment and soft environment of ideological and political education. Thus, high importance shall be attached to the following two issues: firstly, give full play to the important role of each college department, and complete tasks provided in evaluation indexes more seriously. As a systematic project, the construction of college ideological and political education evaluation system is directly related to each department of colleges. College departments shall firstly provide their most important educational resources, formulate ideological and political education index system that complies with their actual conditions, and then colleges would sort indexes of each department more accurately, adhere to the basic principle of giving overall consideration, and finally practically form valuable and efficient integrity and truly become a unified college ideological and political education evaluation index system. Meanwhile, college ideological and political education evaluation shall also go deep into college students, accumulate evaluation indexes fully, and thus formulate a modern educational evaluation index system that truly complies with actual conditions and needs of colleges. As an important element of overall processed ideological and political education model, educational evaluation requires developers to do specific work well more seriously and responsibly, such as, integrate college educational resources fully, experience college cultural environment comprehensively, know about college students' actual thoughts more explicitly, make clear of value orientation of ideological and political education etc, and based on which formulate a new educational evaluation system that complies more with the reality of college students and colleges.

\section{Conclusions}

In general, overall process thinking shall run through college ideological and political education, so that education could truly enjoy popular support and students could achieve better individual development. This requires college ideological and political educators to carry out overall processed management of ideological and political work, make college students accept the new stage with benign development of ideological and political education, show good style of today's young college students, and promote students to have better employment and achieve success in order to lay a solid foundation for their future development.

\section{Acknowledgments}

This paper is a School-level Scientific Research Project of the Year of 2013 of Neijiang Normal University: "Study on Daily Ideological and Political Education and Socialization of College Students” (Project No.: 13SZ05).

\section{References}

[1] Huang Daren. Be Nice to Students: the Overall Process of Containing Ideological and Political Education into College Education [J]. Study of Ideological Education, 2010 (8).

[2] Liang Yuchun. The Research on the Working Mechanism of the Construction of Omni-directional, Overall Processed and Total Ideological and Political Education to the Students 
of Colleges and Universities in Xinjiang [J]. Journal of Kashgar Teachers College, 2011 (2).

[3] Fan Yuejin. Written Conversation on "Omni-directional and Overall Processed College Ideological and Political Education Model” [J]. Journal of Jinan University (Social Sciences), 2012 (5).

[4] Yang Lizhi. Theoretical System and Establishment of Omni-directional and Overall Processed College Ideological and Political Education Model [J]. Journal of Jinan University (Social Sciences), 2012 (5).

[5] Guo Xiuping. Exploration and Analysis of Practice Teaching Paths under Overall Processed Ideological and Political Education Model [J]. Education Teaching Forum, 2013 (3). 